\title{
Cystofilobasidiales, a new order of basidiomycetous yeasts
}

\author{
Jack W. Fell, ${ }^{1}$ Henri Roeijmans ${ }^{2}$ and T. Boekhout ${ }^{3}$ \\ Author for correspondence: Jack W. Fell. Tel: +1305361 4603. Fax: +13053614600 . \\ e-mail: jfell@rsmas.miami.edu
}

\footnotetext{
1 Rosenstiel School of Marine and Atmospheric Science, University of Miami, 4600 Rickenbacker Causeway, Key Biscayne, FL 33149, USA

2 Centraalbureau voor Schimmelcultures, Oosterstraat 1, 3742 SK Baarn, The Netherlands

3 Centraalbureau voor Schimmelcultures, Yeast Division, Julianalaan 67 , 2628 BC Delft,

The Netherlands
}

\begin{abstract}
The order Cystofilobasidiales is described for teleomorphic basidiomycetous yeasts with holobasidia and teliospores. Their septa have dolipores, but lack parenthesomes. D-Glucuronate, nitrate and nitrite are assimilated and myoinositol is usually assimilated. Coenzyme $Q$ has $\mathbf{8}$ or 10 isoprenologues. $25 S$ and 185 rDNA sequence analysis indicates a monophyletic branch within the Tremellomycetidae of the Hymenomycetes. Cystofilobasidium is the type genus.
\end{abstract}

Keywords: phylogeny, basidiomycetes, yeast, rDNA, Cystofilobasidiales

\section{INTRODUCTION}

The assessment of relationships among basidiomycetous yeasts has been hampered by the absence of phylogenetically informative characters; affinity among these organisms was inferred using morphological, biochemical and physiological characters (von Arx et al., 1977; Boekhout et al., 1993; van der Walt, 1987; Kurtzman \& Fell, 1998). Features considered useful were cell wall composition (Prillinger et al., 1993; Roeijmans et al., 1998; Sugiyama et al., 1985; Weijman \& Golubev, 1987; Weijman \& Rodrigues de Miranda, 1988), septal ultrastructure (Boekhout et al., 1992; McLaughlin et al., 1995; Moore, 1987; Suh et al., 1993), morphology of the basidium (Bandoni, 1995; Boekhout et al., 1993; Oberwinkler, 1987), killer sensitivity patterns (Golubev \& Boekhout, 1995) and specific physiological traits such as assimilation of myo-inositol and D-glucuronate (Golubev, 1989), production of extracellular starch-like compounds (Boekhout et al., 1993; Sampaio \& Fonseca, 1995), assimilation of nitrate and nitrite, vitamin requirements (Sampaio \& Fonseca, 1995) and ubiquinone composition (Sugiyama et al., 1985; Yamada et al., 1987). As a result, both anamorphic and teleomorphic basidiomycetous yeasts were divided into two or three main groups (Boekhout et al., 1993; Sampaio \& Fonseca, 1995; van der Walt, 1987).

Recent molecular phylogenetic studies of basidiomycetous yeasts, using $18 \mathrm{~S}$ rDNA sequences, indicated

The GenBank accession numbers for the sequences reported in this paper are AF075463-AF075526. the presence of three classes of Basidiomycota, namely Hymenomycetes, Urediniomycetes and Ustilaginomycetes (Swann \& Taylor, 1995a, b). Based on studies of $25 \mathrm{~S}$ rDNA sequences, yeast stages were found to occur in all of these classes (Boekhout et al., 1995; Fell et al., 1995). A monophyletic cluster of species occurs within the Tremellomycetidae of the Hymenomycetes (Swann \& Taylor, 1995c), that we propose to recognize as the new order Cystofilobasidiales.

\section{METHODS}

Strains. Species and strains investigated are shown in Table 1. Wherever possible, type strains were investigated. Many filamentous species, such as species of Tremella and Sirobasidium, do not have designated living type strains.

Carbohydrate patterns and coenzyme Q measurement. Carbohydrate patterns were determined by analysis of whole-cell hydrolysates with GLC/MS (Roeijmans et al., 1998). Coenzyme Q (CoQ) was extracted with hexane after saponification of intact cells and purification by TLC. Coenzyme Q systems were identified by reverse-phase TLC (Yamada \& Kondo, 1973; Hiraishi et al., 1984) and by MS. In the latter technique, $3 \mu$ l crude extract was inserted in the quartz sample tube of the direct inlet probe and probe temperature was programmed from 50 to $400^{\circ} \mathrm{C}$. The CoQ components evaporated when the probe temperature exceeded $300{ }^{\circ} \mathrm{C}$. Mass spectra were recorded with an ionizing energy of $70 \mathrm{eV}$ (electron impact) and the CoQ systems were identified by their molecular mass.

Sequencing and sequence analysis. Forward and reverse strands of the $\sim 650$ bp region at the $5^{\prime}$ end of the 1 rDNA were sequenced with an Li-Cor Automated Sequencer using 
Table 1. List of strains examined

\begin{tabular}{|c|c|c|}
\hline Species & CBS strain no.* & GenBank accession no. \\
\hline Bullera crocea Buhagiar & $6714^{\mathrm{T}}$ & $\mathrm{AF} 075508$ \\
\hline Bullera globispora Johri \& Bandoni & $6981^{\mathrm{T}}$ & AF075509 \\
\hline Bullera oryzae Nakase \& Suzuki & $7194^{\mathrm{T}}$ & AF075511 \\
\hline Bullera pseudoalba Nakase \& Suzuki & $7227^{\mathrm{T}}$ & AF075504 \\
\hline Bullera unica Hamamoto \& Nakase & $8290^{\mathrm{T}}$ & AF075524 \\
\hline Bulleromyces albus Boekhout \& Fonseca & 501 & AF075500 \\
\hline Cryptococcus aerius (Saito) Skinner & $155^{\mathrm{T}}$ & AF075486 \\
\hline Cryptococcus albidus (Saito) Skinner & $142^{\mathrm{T}}$ & AF075474 \\
\hline Cryptococcus antarcticus Vishniac \& Kurtzman & $7687^{\mathrm{T}}$ & AF075488 \\
\hline Cryptococcus aquaticus (Jones \& Slooff) Rodrigues de Miranda \& Weijman & $5443^{\mathrm{T}}$ & AF075470 \\
\hline Cryptococcus cellulolyticus Nakase et al. & $8294^{\mathrm{T}}$ & AF075525 \\
\hline Cryptococcus diffluens Zach (Lodder \& Kreger-van Rij) & $160^{\mathrm{T}}$ & AF075502 \\
\hline Cryptococcus dimennae Fell \& Phaff & $5770^{\mathrm{T}}$ & AF075489 \\
\hline Cryptococcus feraegula Saëz \& Rodrigues de Miranda & 7201 & AF075487 \\
\hline Cryptococcus flavus (Saito) Phaff \& Fell & $331^{\mathrm{T}}$ & AF075497 \\
\hline Cryptococcus friedmannii Vishniac & $7160^{\mathrm{T}}$ & AF075478 \\
\hline Cryptococcus fuscescens Golubev & $7189^{\mathrm{T}}$ & AF075472 \\
\hline Cryptococcus heveanensis (Groenewege) Baptist \& Kurtzman & $569^{\mathrm{T}}$ & AF075467 \\
\hline Cryptococcus hungaricus (Zsolt) Phaff \& Fell & $4214^{\mathrm{T}}$ & AF075503 \\
\hline Cryptococcus laurentii (Kufferath) Skinner & $139^{\mathrm{T}}$ & AF075469 \\
\hline Cryptococcus luteolus Skinner & $943^{\mathrm{T}}$ & AF075482 \\
\hline Cryptococcus macerans (Frederiksen) Phaff \& Fell & $2425^{\mathrm{MT}}$ & AF075477 \\
\hline Cryptococcus podzolicus (Babjeva \& Reshetova) Golubev & $6819^{\mathrm{T}}$ & AF075481 \\
\hline Cryptococcus skinneri Phaff \& do Carmo-Sousa & $7890 \dagger$ & AF075494 \\
\hline Cryptococcus terreus di Menna & $1895^{\mathrm{T}}$ & AF075479 \\
\hline Cryptococcus vishniacii Vishniac \& Hempfling & $7110^{\mathrm{T}}$ & AF075473 \\
\hline Cystofilobasidium bisporidii (Fell et al.) Oberwinkler \& Bandoni & $6347^{\mathrm{MT}}$ & AF075464 \\
\hline Cystofilobasidium capitatum (Fell et al.) Oberwinkler \& Bandoni & $6358^{\mathrm{T}}$ & AF075465 \\
\hline Cystofilobasidium infirmominiatum (Fell et al.) Hamamoto et al. & $323^{\mathrm{T}}$ & AF075505 \\
\hline Cystofilobasidium lari-marini (Saëz \& Nguyen) Fell \& Statzell-Tallman & $7420^{\mathrm{T}}$ & AF075466 \\
\hline Fellomyces fuzhouensis (Yue) Yamada \& Banno & 6133 & AF075506 \\
\hline Filobasidiella neoformans var. bacillispora Kwon-Chung & $6289^{\mathrm{MT}}$ & AF075526 \\
\hline Filobasidiella neoformans var. neoformans Kwon-Chung & $132^{\mathrm{T}}$ & AF075484 \\
\hline Filobasidium capsuligenum Rodrigues de Miranda & $4736^{\mathrm{T}}$ & AF075501 \\
\hline Filobasidium floriforme Olive & $6241^{\mathrm{T}}$ & AF075498 \\
\hline Filobasidium globisporum Bandoni \& Oberwinkler & 7642 & AF075495 \\
\hline Filobasidium uniguttulatum Kwon-Chung & $1730^{\mathrm{T}}$ & AF075468 \\
\hline Kockovaella thailandica Nakase et al. & $7552^{\mathrm{T}}$ & AF075516 \\
\hline Mrakia frigida (Fell et al.) Yamada \& Komagata & $5270^{\mathrm{T}}$ & AF075463 \\
\hline Rhodotorula diffluens (Ruinen) von Arx \& Weijman & $5233^{\mathrm{T}}$ & AF075485 \\
\hline Rhodotorula foliorum (Ruinen) Rodrigues de Miranda \& Weijman & 6370 & AF075499 \\
\hline Rhodotorula philyla (van der Walt et al.) Rodrigues de Miranda \& Weijman & $6272^{\mathrm{T}}$ & AF075471 \\
\hline Sirobasidium intermedium Kundalkar \& Patil (yeast phase) & 7805 & AF075492 \\
\hline Sirobasidium magnum Boedijn & 6803 & AF075475 \\
\hline Sporobolomyces falcatus Santa Maria & $7368^{\mathrm{T}}$ & AF075490 \\
\hline Sterigmatosporidium polymorphum Kraepelin \& Schulze & $8088^{\mathrm{T}}$ & AF075480 \\
\hline Tremella fuciformis Berkeley (yeast state) & 6970 & AF075476 \\
\hline Tremella mesenterica Retzius: Fries (yeast state) & 6973 & AF075518 \\
\hline Tremella moriformis Smith \& Sowerby (yeast state) & $7810^{\mathrm{T}}$ & AF075493 \\
\hline Trichosporon aquatile Hedrick \& Dupont & $5973^{\mathrm{T}}$ & AF075520 \\
\hline Trichosporon asteroides (Rischin) Ota & $2481^{\mathrm{T}}$ & AF075513 \\
\hline Trichosporon brassicae Nakase & $6382^{\mathrm{T}}$ & AF075521 \\
\hline Trichosporon cutaneum (de Beurmann et al.) Ota & $2466^{\mathrm{T}}$ & AF075483 \\
\hline Trichosporon domesticum Sugita et al. & $8280^{\mathrm{T}}$ & AF075512 \\
\hline Trichosporon dulcitum (Berhout) Weijman & $8257^{\mathrm{T}}$ & AF075517 \\
\hline Trichosporon laibachii (Windisch) Guého \& Smith & $5790^{\mathrm{T}}$ & AF075514 \\
\hline Trichosporon loubieri (Morenz) Weijman & $7065^{\mathrm{T}}$ & AF075522 \\
\hline Trichosporon mucoides Guého \& Smith & $7625^{\mathrm{T}}$ & AF075515 \\
\hline Trichosporon ovoides Behrend & $7556^{\mathrm{T}}$ & AF075523 \\
\hline Trimorphomyces papilionaceus Oberwinkler \& Bandoni & 445.92 & AF075491 \\
\hline Udeniomyces megalosporus (Nakase \& Suzuki) Nakase \& Takematsu & $7236^{\mathrm{T}}$ & AF075510 \\
\hline Udeniomyces puniceus (Komagata \& Nakase) Nakase \& Takematsu & $5689^{\mathrm{T}}$ & AF075519 \\
\hline Udeniomyces pyricola (Stadelmann) Nakase \& Takematsu & $6754^{\mathrm{T}}$ & AF075507 \\
\hline Xanthophyllomyces dendrorhous Golubev & $7918^{\mathrm{T}}$ & AF075496 \\
\hline
\end{tabular}

* CBS, Centraalbureau voor Schimmelcultures, The Netherlands. ${ }^{\mathrm{T}}$, Type strain; ${ }^{\mathrm{MT}}$, mating type.

$\dagger$ Note added in proof. CBS 7890 was originally identified as Cryptococcus skinneri in the CBS database. Subsequent examination of CBS $5029^{\mathrm{T}}$, the type strain of $C$. skinneri, demonstrated that the two strains are phylogenetically distinct. CBS 5029 $9^{\mathrm{T}}$ occurs in the same clade as $C$. luteolus in Fig. 1. CBS 7890 represents an undescribed species. 
a standard protocol with forward primer 5' GCATATCAATAAGCGGAGGAAAAG and reverse primer $5^{\prime}$ GGTCCGTGTTTCAAGACG. Alignments were prepared with MegAlign (DNAStar) and visually corrected. Phylogenetic trees were computed with PAUP (test version 4.0d61, used with the permission of D. Swofford) using parsimony analysis (heuristic search, random stepwise addition, nearestneighbour interchange, 100 maximum trees). Bootstrap analysis was based on 1000 replicates.

\section{RESULTS AND DISCUSSION}

Yeasts classified in the Tremellomycetidae (Hymenomycetes) are characterized by the presence of dolipore septa, xylose in the cell walls and, with some exceptions, utilization of myo-inositol and Dglucuronate, and production of starch-like compounds. Fig. 1 is a representative analysis of the Tremellomycetidae; the number of species in this figure was limited to increase the visual clarity of the tree. There are two major branches, one of which contains genera of the Tremellales/Filobasidiales and the other branch consists of the teleomorphic genera Mrakia and Cystofilobasidium, the anamorphic genus Udeniomyces and two species of Cryptococcus. The Tremellales and Filobasidiales are characterized by a sexual cycle that lacks a teliosporic probasidium and by the morphology of the septal pores. Species of Bulleromyces, Sirobasidium, Sterigmatosporidium, Tremella and relatives, and Filobasidium have Tremellales-type dolipores with tubular, vesiculate or 'U'-shaped parenthesomes (Boekhout et al., 1993; Kwon-Chung et al., 1995; McLaughlin et al., 1995; Moore \& Kreger-van Rij, 1972; Oberwinkler \& Bandoni, 1982). The reported absence of a parenthesome in Filobasidium floriforme can be questioned, as a Tremellales-type parenthesome appears to be present in Fig. 4 of Moore \& Kreger-van Rij (1972). Parenthesomes are generally considered as modified compartments of the endoplasmic reticulum (Moore, 1985), which may play an important role in intercellular signalling and maintenance of homeostasis (Mueller et al., 1998).

There are two sub-branches within the Tremellales/ Filobasidiales: one sub-branch, which is weakly supported $(58 \%)$ by bootstrap analysis, consists of species of Tremella, Bulleromyces, Filobasidiella, etc. The anamorphic genus Trichosporon, which is included in this cluster, is supported (bootstrap value $81 \%$ ) as a cohesive group. This genus, which is characterized by the presence of arthroconidia, was studied in detail by Guého et al. (1992). The other sub-branch, which has a bootstrap support of $90 \%$, includes Filobasidium and several species of Cryptococcus. These data suggest that the Filobasidiales are phylogenetically distinct from the Tremellales. The sequence analysis also demonstrates a separate Cystofilobasidiales clade within the Tremellomycetidae of the Hymenomycetes, with a bootstrap value of $87 \%$ (Fig. 1). Two subclades can be discerned: (1) Mrakia frigida, Cryptococcus aquaticus and Udeniomyces spp. (90\% support); and (2) Cryptococcus feraegula, Cryptococcus macerans and Cystofilobasidium spp. $(100 \%)$. These results agree with 18S rDNA data, which support the Cystofilobasidium-Mrakia clade with $98 \%$ bootstrap values (Suh \& Nakase, 1995; Swann \& Taylor, 1995a, b). The two teleomorphic genera in these clades, Mrakia and Cystofilobasidium, produce teliospores, a characteristic not found among other hymenomycetous yeasts. Metabasidia differ between the two genera: teliospore germination in Mrakia results in short $(\sim 8 \times 5 \mu \mathrm{m})$ holo- or phragmometabasidia; whereas, most species of Cystofilobasidium produce a long, thin (up to $80 \times 2.7 \mu \mathrm{m}$ ) holobasidium with a capitate apex (Kwon-Chung, 1998).

The distribution of other character states among the species of Cystofilobasidiales is given in Table 2. Two different CoQ systems occur: CoQ 8 occurs in all species except for Udeniomyces spp., which contain CoQ 10 (Boekhout et al., 1992; Guého et al., 1993; Nakase \& Suzuki, 1986; Nakase \& Takematsu, 1992; Suh \& Sugiyama, 1993; Sugiyama et al., 1985; Yamada \& Komagata, 1987; Yamada \& Kondo, 1972, 1973; Yamada \& Matsumoto, 1989). The different genes involved in the biosynthesis of distinct CoQ molecules (CoQ 7, 8,9 or 10) may be present in a single organism. This possibility is suggested by the report of the occurrence of minor CoQ fractions in concert with one or two major CoQ fractions (Billon-Grand, 1988; Kuraishi et al., 1985) and by the observation that the relative proportions of these different $\mathrm{CoQ}$ fractions are influenced by environmental conditions (BillonGrand, 1989). If this supposition is true, the presence of two different major CoQ molecules among the Cystofilobasidiales may be the result of differences in gene expression with limited phylogenetic significance. It should be noted, however, that CoQ 10 is confined to the ballistoconidia-forming species and CoQ 8 to the teliospore-forming yeasts and closely related anamorphs.

All species of Cystofilobasidiales contain xylose in their cell walls (von Arx \& Weijman, 1979; Boekhout et al., 1992; Elinov et al., 1974; Golubev, 1995; Gorin \& Spencer, 1970; Roeijmans et al., 1989; Sugiyama et al., 1985; Suh \& Sugiyama, 1993; Weijman, 1979; Weijman \& Rodrigues de Miranda, 1988). DGlucuronate, nitrate and nitrite are assimilated by all species, myo-inositol is used by most species, except Cryptococcus aquaticus, most species are dependent on thiamine and biotin, and fermentative capabilities occur in Cystofilobasidium lari-marini (Barnett et al., 1990; Kwon-Chung, 1998). Hyphal septa of investigated species of the Cystofilobasidiales, namely Mrakia frigida and Cystofilobasidium spp., have dolipores without parenthesomes (Oberwinkler et al., 1983; Suh \& Sugiyama, 1993; Suh et al., 1993). The argument can be presented that dolipores without parenthesomes are plesiomorphic when compared with dolipores with vesiculate, tubular or ' $U$ '-shaped, 


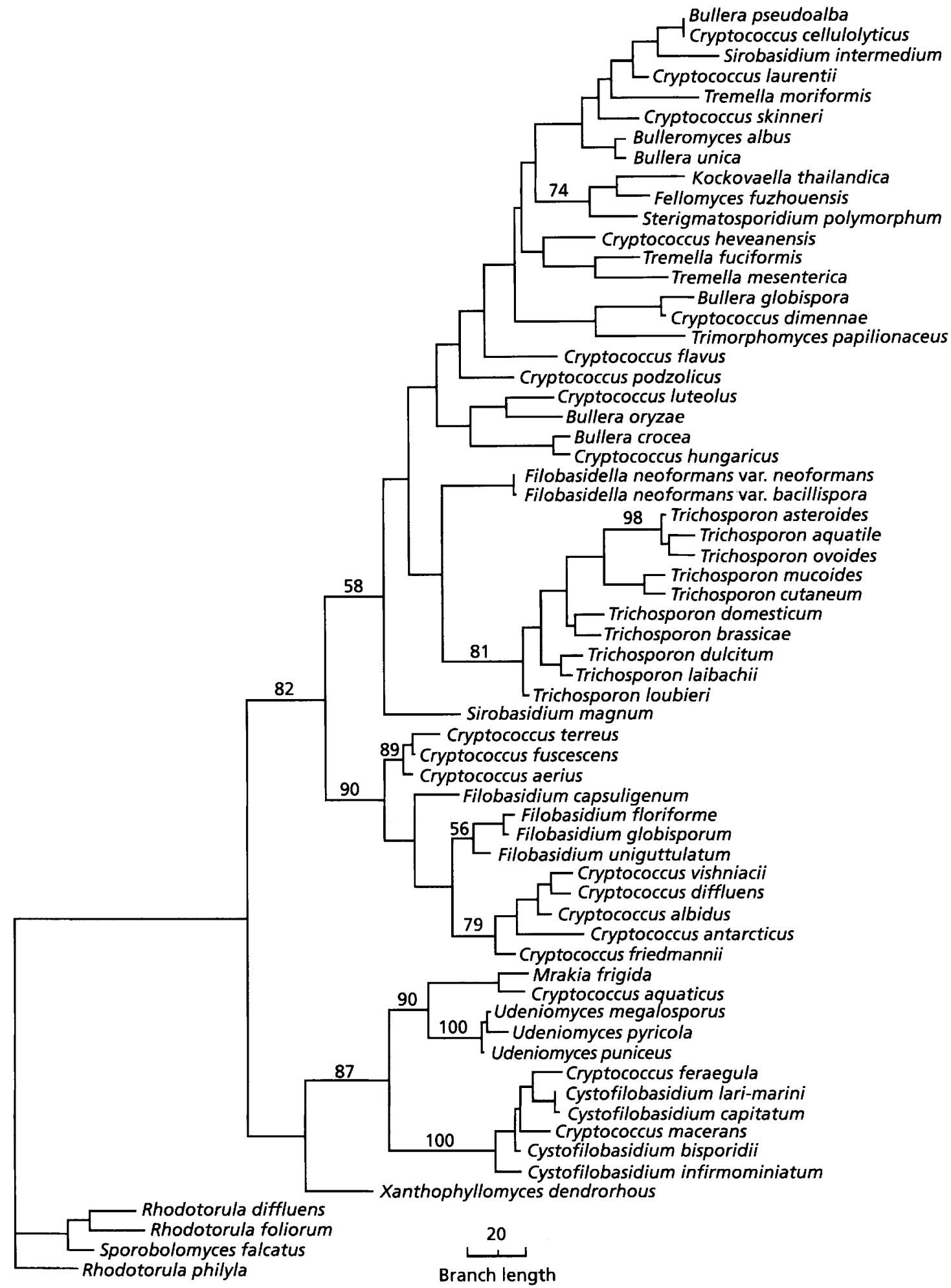

Fig. 1. Phylogenetic tree of yeasts of the Tremellomycetidae derived from parsimony analysis (heuristic search, random stepwise addition, nearest-neighbour interchange, 100 maximum trees). Branch lengths are proportional to the number of nucleotide differences. The numbers given on branches are the frequencies (percentages) that a given branch appeared in 1000 bootstrap replicates (PAUP test version 4.0d61, used with the permission of D. Swofford). Species of Urediniomycetes (Rhodotorula and Sporobolomyces) were used as an outgroup. 
Table 2. Summary of salient characteristics of Cystofilobasidiales species

CoQ, Coenzyme Q; Xylose, presence of xylose in cell-free extract; Telio, formation of teliospore; Basidia, absence of basidium (-) or presence of holometabasidium (HOLO); Septa, septal type unknown (?) or presence of dolipore (DOLI); Inositol, assimilation of myo-inositol; D-Gluc, assimilation of D-glucuronate; Starch, production of starch-like compounds; $\mathrm{NO}_{3}$ and $\mathrm{NO}_{2}$, assimilation of nitrate and nitrite; w/o Thiamine/Biotin, growth in the absence of either of those vitamin sources. V, Variable reaction; w, weak reaction, D, delayed; *, new data. Other data from Barnett et al. (1990) and Kurtzman \& Fell (1998).

\begin{tabular}{|c|c|c|c|c|c|c|c|c|c|c|c|c|}
\hline Species & CoQ & Xylose & Telio & Basidia & Septa & Inositol & D-Gluc & Starch & $\mathrm{NO}_{3}$ & $\mathrm{NO}_{2}$ & $\begin{array}{c}\text { w/o } \\
\text { Thiamine }\end{array}$ & $\begin{array}{c}\text { w/o } \\
\text { Biotin }\end{array}$ \\
\hline Cryptococcus aquaticus & $8^{*}$ & + & - & - & $?$ & - & + & + & + & + & - & - \\
\hline Cryptococcus feraegula & $8^{*}$ & $t^{*}$ & - & - & $?$ & + & + & + & + & + & - & - \\
\hline Cryptococcus macerans & $8^{*}$ & + & - & - & $?$ & + & + & + & + & + & - & - \\
\hline Cystofilobasidium bisporidii & 8 & + & + & HOLO & DOLI & + & + & $v$ & + & + & - & - \\
\hline Cystofilobasidium capitatum & 8 & + & + & HOLO & DOLI & + & + & + & + & + & - & $\mathrm{v}$ \\
\hline Cystofilobasidium infirmominiatum & 8 & + & + & HOLO & DOLI & + & + & + & + & + & - & - \\
\hline Cystofilobasidium lari-marini & 8 & + & + & HOLO & DOLI & $\mathrm{v}$ & + & + & + & + & - &,$- \mathrm{D}$ \\
\hline Mrakia frigida & 8 & + & + & HOLO & DOLI & $\mathrm{v}$ & + & + & + & + & - &,$- \mathrm{D}$ \\
\hline Udeniomyces megalosporus & 10 & + & - & - & $?$ & - & + & + & + & + & - & - \\
\hline Udeniomyces pyricola & 10 & + & - & - & $?$ & + & + & $\mathrm{w}$ & + & + & - & - \\
\hline Udeniomyces puniceus & 10 & + & - & - & $?$ & + & + & + & + & + & - & - \\
\hline
\end{tabular}

plate-like or perforate parenthesomes. However, detailed studies on the biogenesis, differentiation and function of the septum-parenthesome complex in different groups of hymenomycetous fungi, e.g. Auriculariales, Cystofilobasidiales, Filobasidiales, Exidiales, Tremellales and higher fungi (e.g. Agaricales), are necessary to understand the evolutionary importance of these structures. Preparation techniques, such as high-pressure freezing, freeze substitution and cryo-electron microscopy, are essential to avoid artifacts (Mueller et al., 1995; Orlovich \& Ashford, 1994) which may hamper correct interpretations. This requirement is illustrated by conflicting results in different studies on the septal ultrastructure of Filobasidiella depauperata (Kwon-Chung et al., 1995; Rhodes et al., 1981).

Our analysis of rDNA sequences demonstrates that three species of Cryptococcus are members of the Cystofilobasidiales (Fig. 1). Based on this apparent relationship, the hypothesis can be offered that Cryptococcus macerans and Cryptococcus feraegula may have a Cystofilobasidium-type life cycle, whereas the life cycle of Cryptococcus aquaticus may be similar to Mrakia. Xanthophyllomyces dendrorhous (Phaffia rhodozyma) may be related to Cystofilobasidiales as indicated by $18 \mathrm{~S}$ data (Swann \& Taylor, 1995c); however, inclusion in this clade is not supported by bootstrap analysis (Fig. 1) using 25S rDNA data. Parsimony analysis indicated that two other species, Trichosporon pullulans and Itersonila perplexans, may be weakly related to the Cystofilobasidiales (Fell et al., 1995), but bootstrap analysis did not support their inclusion. Both species differ from the Cystofilobasidiales by the presence of CoQ 9. As more data accumulates regarding peripherally related species, our vision of Cystofilobasidiales may alter. Similarly, the present definitions of the Tremellales and Filobasidiales must be evaluated to consider such problems as the phylogenetic placement of Filobasidiella.

\section{Latin diagnosis of Cystofilobasidiales Boekhout \& Fell}

Cystofilobasidiales, order novus Basidiomycetum, species plerumque zymosae; taxa meiosporica, heterothallica vel ipsifertilia. Teliosporae vulgo formatae; basidia si praesentia, unicellularia. Coenzymum $Q 8$ vel 10. Parietes cellularum xylosium continentes. Septa hypharum plerumque doliporis parenthesomate carentibus praedita, sed nonnumquam imperforata. DGlucuronatum, nitratum et nitritum assimilantur. Sequentiae rDNA positionem in hymenomycetibus indicantes. Genus typicum Cystofilobasidium Oberwinkler \& Bandoni.

\section{Description of Cystofilobasidiales Boekhout \& Fell}

Basidiomycetous fungi, usually with a free-living yeast phase. Meiotic taxa are heterothallic or selfsporulating (secondarily homothallic?). Teliospores are present. Basidia, if present, are unicellular. CoQ 8 or 10 is present. Cell walls contain xylose. Hyphal septa usually have dolipores without a parenthesome. D-Glucuronate, nitrate and nitrite are assimilated and myo-inositol is usually assimilated. 25S rDNA sequences form a monophyletic branch within the Tremellomycetidae. Type genus is Cystofilobasidium Oberwinkler \& Bandoni.

The following meiotic taxa are included in the Cystofilobasidiales: Cystofilobasidium, including Cystofilobasidium bisporidii (Fell et al.) Oberwinkler \& Bandoni, Cystofilobasidium capitatum (Fell et al.) Oberwinkler \& Bandoni, Cystofilobasidium infirmominiatum (Fell et al.) Hamamoto et al., Cystofilobasidium lari-marini (Saëz \& Nguyen) Fell \& Statzell-Tallman; Mrakia, including Mrakia frigida (Fell et al.) Yamada \& Komagata. The following taxa are only known in their mitotic state, but 25S rDNA sequences indicate that they belong to this order: Cryptococcus, including Cryptococcus aquaticus (Jones 
\& Slooff) Rodrigues de Miranda \& Weijman (Mrakia branch), Cryptococcus feraegula Saëz \& Rodrigues de Miranda, Cryptococcus macerans (Frederiksen) Phaff \& Fell (Cystofilobasidium branch); Udeniomyces, including Udeniomyces megalosporus (Nakase \& Suzuki) Nakase \& Takematsu, Udeniomyces puniceus (Komagata \& Nakase) Nakase \& Takematsu, Udeniomyces pyricola (Stadelmann) Nakase \& Takematsu (Udeniomyces branch).

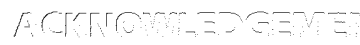

Funding to J.W.F. was provided by the National Science Foundation (Biological Oceanography and Systematic Biology). Gina Blatt, Gloria Scorzetti and Adele StatzellTallman (University of Miami) provided invaluable assistance in developing and preparing the sequence data.

\section{REFERENCES}

von Arx, J. A. \& Weijman, A. C. M. (1979). Conidiation and carbohydrate composition in some Candida and Torulopsis species. Antonie Leeuwenhoek 45, 547-555.

von Arx, J. A., Rodrigues de Miranda, L., Smith, M. T. \& Yarrow, D. (1977). The genera of the yeasts and the yeast-like fungi. Stud Mycol 14, 1-42.

Bandoni, R. J. (1995). Dimorphic heterobasidiomycetes: taxonomy and parasitism. Stud Mycol 38, 13-27.

Barnett, J. A., Payne, R. W. \& Yarrow, D. (1990). Yeasts: Characteristics and Identification, 2nd edn. Cambridge: Cambridge University Press.

Billon-Grand, G. (1988). Contribution la taxonomie et la phylogenie des levures. Apport du critère 'Coenzyme $Q$ '. PhD thesis, Université Claude Bernard, Lyon, France.

Billon-Grand, G. (1989). Influence on minor peaks of coenzyme $\mathrm{Q}$ of the glucose concentration in the culture medium, the stage of the growth cycle, and the duration of the coenzyme $Q$ extraction: required conditions for determining the minor coenzymes Q. J Gen Appl Microbiol 35, 261-268.

Boekhout, T., Yamada, Y., Weijman, A. C. M., Roeijmans, H. J. \& Batenburg-van der Vegte, W. H. (1992). The significance of coenzyme $\mathrm{Q}$, carbohydrate composition and septal ultrastructure for the taxonomy of ballistoconidia-forming yeasts and fungi. Syst Appl Microbiol 15, 1-10.

Boekhout, T., Fonseca, A., Sampaio, J.-P. \& Golubev, W. I. (1993). Classification of heterobasidiomycetous yeasts: characteristics and affiliation of genera to higher taxa. Can J Microbiol 39, 276-290.

Boekhout, T., Fell, J. W. \& O'Donnell, K. (1995). Molecular systematics of some yeast-like anamorphs belonging to the Ustilaginales and Tilletiales. Stud Mycol 38, 175-183.

Elinov, N. P., Vitovskaya, G. A., Kaloshin, V. G. \& Kolotinskaya, T. M. (1974). Structural polysaccharides of some species of Rhodotorula and Cryptococcus. Biokhimiya 39, 787-792.

Fell, J. W., Boekhout, T. \& Freshwater, D. W. (1995). The role of nucleotide sequence analysis in the systematics of the yeast genera Cryptococcus and Rhodotorula. Stud Mycol 38, 129-146.

Golubev, W. I. (1989). Catabolism of i-inositol and taxonomic value of D-glucuronate assimilation in yeasts. Mikrobiologiya 58, 276-283.

Golubev, W. I. (1995). Perfect state of Rhodomyces dendrorhous (Phaffia rhodozyma). Yeast 11, 101-110.

\section{Mycol 38, 47-58.}

Gorin, P. A. J. \& Spencer, J. F. T. (1970). Proton magnetic resonance spectroscopy as an aid in identification and chemotaxonomy of yeasts. Adv Appl Microbiol 13, 25-89.

Guého, E., Smith, M. Th., de Hoog, G. S., Billon-Grand, G., Christen, R. \& Batenburg-van der Vegte, W. H. (1992). Contributions to a revision of the genus Trichosporon. Antonie Leeuwenhoek 61, 289-316.

Guého, E., Improvisi, L., Christen, R. \& de Hoog, G. S. (1993). Phylogenetic relationships of Cryptococcus neoformans and some related basidiomycetous yeasts determined from partial large subunit rRNA sequences. Antonie Leeuwenhoek 63, 175-189.

Hiraishi, A., Hoshino, Y. \& Kitamura, H. (1984). Isoprenoid quinone composition in the classification of Rhodospirillaceae. J Gen Appl Microbiol 30, 197-210.

Kuraishi, H., Katayama-Fujimura, Y., Sugiyama, J. \& Yokoyama, T. (1985). Ubiquinone systems in fungi I. Distribution of ubiquinones in the major families of ascomycetes, basidiomycetes, and deuteromycetes, and their taxonomic implications. Trans Mycol Soc Jpn 26, 383-395.

Kurtzman, C. P. \& Fell, J. W. (1998). The Yeasts: a Taxonomic Study, 4th edn. Amsterdam: Elsevier.

Kwon-Chung, K. J. (1998). Cystofilobasidium Oberwinkler, Bandoni, Blanz, Kishimova-Horovitz. In The Yeasts: a Taxonomic Study, 4th edn, pp. 650-657. Edited by C. P. Kurtzman \& J. W. Fell. Amsterdam: Elsevier.

Kwon-Chung, K. J., Chang, Y. C., Bauer, R., Swann, E. C., Taylor, J. W. \& Goel, R. (1995). The characteristics that differentiate Filobasidiella depauperata from Filobasidiella neoformans. Stud

McLaughlin, D. J., Frieders, M. E. \& Lue, H. (1995). A microscopist's view of heterobasidiomycete phylogeny. Stud

Moore, R. T. (1985). The challenge of the dolipore/parenthesome septum. In Developmental Biology of Higher Fungi, pp. 175-212. Edited by D. Moore, L. A. Casselton, D. A. Wood \& J. A. Frankland. Cambridge: Cambridge University Press.

Moore, R. T. (1987). Micromorphology of yeasts and yeast-like fungi and its taxonomic implications. Stud Mycol 30, 203-226.

Moore, R. T. \& Kreger-van Rij, N. J. W. (1972). Ultrastructure of Filobasidium. Can J Microbiol 18, 1949-1951.

Mueller, W. H., van Aelst, A. V., van der Krift, T. \& Boekhout, T. (1995). Novel approaches to visualize the septal pore cap. Stud

Mueller, W. H., Humbel, B. M., van Aelst, A. C., van der Krift, T. \& Boekhout, T. (1998). Intercellular exchange through perforate septal pore caps in homobasidiomycetes. In Plasmodesmata: Nanochannels with Megatasks. Edited by A. van Bel. Berlin: Springer (in press).

Nakase, T. \& Suzuki, M. (1986). The ubiquinone system in strains of species in the ballistospore-forming yeast genera Sporidiobolus, Sporobolomyces and Bullera. J Gen Appl Microbiol 32, 251-258.

Nakase, T. \& Takematsu, A. (1992). Udeniomyces, a new ballistosporous anamorphic yeast genus in the Cryptococcaceae proposed for three Bullera species which produce large bilaterally symmetrical ballistospores. FEMS Microbiol Lett 100 , 497-502. 
Oberwinkler, F. (1987). Heterobasidiomycetes with ontogenetic yeast-stages. Systematic and phylogenetic aspects. Stud Mycol 30, 61-74.

Oberwinkler, F. \& Bandoni, R. J. (1982). Trimorphomyces: a new genus in the Tremellaceae. Syst Appl Microbiol 4, 105-113.

Oberwinkler, F., Bandoni, R. J. \& Kisimova-Horovitz, L. (1983). Cystofilobasidium: a new genus in the Filobasidiaceae. Syst Appl Microbiol 4, 114-122.

Orlovich, D. A. \& Ashford, A. E. (1994). Structure and development of the dolipore septum in Pisolithus tinctorius. Protoplasma 178, 66-80.

Prillinger, H., Oberwinkler, F., Umile, C., Tlachac, K., Bauer, R., Dörfler, C. \& Taufratzhofer, E. (1993). Analysis of cell wall carbohydrates (neutral sugars) from ascomycetous and basidiomycetous yeasts with and without derivatization. $J$ Gen Appl Microbiol 39, 1-34.

Rhodes, J. C., Kwon-Chung, K. J. \& Popkin, T. J. (1981). Ultrastructure of the septal complex in hyphae of Cryptococcus laurentii. J Bacteriol 145, 1410-1412.

Roeijmans, H. J., van Eijk, G. W. \& Yarrow, D. (1989). Some name changes necessitated by the redefinition of the genus Candida. Mycotaxon 35, 405-406.

Roeijmans, H., Prillinger, H., Umile, C., Sugiyama, J., Nakase, T. \& Boekhout, T. (1998). Analysis of carbohydrate composition of cell walls and extracellular carbohydrates. In The Yeasts: a Taxonomic Study, 4th edn, pp. 103-105. Edited by C. P. Kurtzman \& J. W. Fell. Amsterdam: Elsevier.

Sampaio, J. P. \& Fonseca, A. (1995). Physiological aspects in the systematics of heterobasidiomycetous yeasts. Stud Mycol 38, $29-46$.

Sugiyama, J., Fukagawa, M., Chiu, S. W. \& Komagata, K. (1985). Cellular carbohydrate composition, DNA base composition, ubiquinone systems, and diazonium blue B colour test in the genera Rhodosporidium, Leucosporidium, Rhodotorula and related basidiomycetous yeasts. J Gen Appl Microbiol 31, 519-550.

Suh, S. O. \& Nakase, T. (1995). Phylogenetic analysis of the ballistosporous anamorphic genera Udeniomyces and Bullera, and related basidiomycetous yeasts, based on 18S rDNA sequence. Microbiology 141, 901-906.

Suh, S. O. \& Sugiyama, J. (1993). Septal pore ultrastructure of Leucosporidium lari-marini, a basidiomycetous yeast, and its taxonomic implications. J Gen Appl Microbiol 39, 257-260.

Suh, S. O., Hirata, A., Sugiyama, J. \& Komagata, K. (1993). Septal ultrastructure of basidiomycetous yeasts and their taxonomic implications with observations on the ultrastructure of Erythrobasidium hasegawianum and Sympodiomycopsis paphiopedili. Mycologia 85, 30-37.

Swann, E. C. \& Taylor, J. W. (1995a). Phylogenetic perspectives on basidiomycete systematics: evidence from the $18 \mathrm{~S}$ rRNA gene. Can J Bot 73, S862-S868.

Swann, E. C. \& Taylor, J. W. (1995b). Phylogenetic diversity of yeast-producing basidiomycetes. Mycol Res 99, 1205-1210.

Swann, E. C. \& Taylor, J. W. (1995c). Toward a phylogenetic systematics of the Basidiomycota: integrating yeasts and filamentous basidiomycetes using 18S rRNA gene sequences. Stud Mycol 38, 147-161.

van der Walt, J. P. (1987). The yeasts - a conspectus. Stud Mycol 30, 19-31.

Weijman, A. C. M. (1979). Carbohydrate composition of Geotrichum, Trichosporon and allied genera. Antonie Leeuwenhoek 45, 119-127.

Weijman, A. C. M. \& Golubev, W. I. (1987). Carbohydrate patterns and taxonomy of yeasts and yeast-like fungi. Stud Mycol 30, 361-371.

Weijman, A. C. M. \& Rodrigues de Miranda, L. (1988). Carbohydrate patterns of the genera Candida, Rhodotorula, and Cryptococcus. Antonie Leeuwenhoek 54, 535-543.

Yamada, Y. \& Komagata, K. (1987). Mrakia gen. nov., a heterobasidiomycetous yeast genus for the Q8-equipped, selfsporulating organism which produces a unicellular metabasidium, formerly classified in the genus Leucosporidium. $J$ Gen Appl Microbiol 33, 455-457.

Yamada, Y. \& Kondo, K. (1972). Taxonomic significance of the coenzyme $Q$ system in yeasts and yeast-like fungi. Proceedings of the 4th International Fermentation Symposium, Kyoto, Japan. Ferment Technol Today 781-784.

Yamada, Y. \& Kondo, K. (1973). Coenzyme Q system in the classification of the yeast genera Rhodotorula and Cryptococcus, and the yeast-like genera Sporobolomyces and Rhodosporidium. J Gen Appl Microbiol 19, 59-77.

Yamada, Y. \& Matsumoto, A. (1989). An electrophoretic comparison of enzymes in strains of species in the genus Mrakia Yamada et Komagata (Filobasidiaceae). J Gen Appl Microbiol 34, 201-208.

Yamada, Y., Banno, I., von Arx, J. A. \& van der Walt, J. P. (1987). Taxonomic significance of the coenzyme $Q$ system in yeasts and yeast-like fungi. Stud Mycol 30, 299-308. 